\title{
NILAI PENDIDIKAN SERAT JAYABAYA KARYA RADEN NGABEHI RONGO WARSITO
}

\section{Djoko Sumarsono $^{1}$, Nurpeni Priyatiningsih ${ }^{2}$, dan R. Adi Deswijaya ${ }^{3}$}

\author{
Program Studi Pendidikan Bahasa dan Sastra Daerah \\ Universitas Veteran Bangun Nusantara Sukoharjo \\ Email: jokosumarsonounivet@gmail.com ${ }^{1}, \underline{\text { nurpenipriyatiningsih@gmail.com }}{ }^{2},{\text { adides } 2016 @ \text { gmail.com }^{3}}^{3}$
}

\begin{abstract}
Abstrak
Penelitian ini terkait dengan ramalan Jayabaya Musarar berhubungan dengan makna yang terkandung dan nilai pendidikan didalamnya. Popularitas Jangka Jayabaya tergolong tinggi dikalangan masyarakat jawa secara umum dan masyarakat Kediri khususnya. Hal ini menunjukkan bahwa kepercayaan terhadap mitologi masih berakar kuat dalam mentalitas masyarakat Indonesia. Serat Musarar adalah gubahan Raden Ngabehi Ranggawarsita yang perlu dilestarikan. Nilai pendidikan karakter yang ditemukan dalam serat Musarar diantaranya:1) Nilai yang berhubungan dengan Tuhan, nilai ini ditemukan diantaranya percaya dan ketaatan kepada Tuhan, 2) Nilai yang berhubungan dengan diri sendiri, Nilai diantaranya kecerdasan, dan cinta ilmu, 3) Nilai yang berhubungan dengan sesama, nilai ini ditemukan pada nilai gotong royong, patuh dan aturan sosial, dan keadilan, 4) Nilai yang berhubungan dengan alam sekitar atau lingkungan, nilai ini berupa sikap dan tindakan yang selalu berupaya mencegah kerusakan pada lingkungan alam sekitarnya, dan 5) Nilai yang berhubungan dengan kebangsaan, nilai ini dapat berupa nasionalis dan menghargai keberagaman.
\end{abstract}

Kata kunci: nilai pendidikan, ramalan, jayabaya.

\section{EDUCATION VALUE OF SERAT JAYABAYA WRITTEN BY RADEN NGABEHI RONGGOWARSITO}

\author{
Djoko Sumarsono ${ }^{1}$, Nurpeni Priyatiningsih ${ }^{2}$, and R. Adi Deswijaya ${ }^{3}$
}

Program Studi Pendidikan Bahasa dan Sastra Daerah

Universitas Veteran Bangun Nusantara Sukoharjo

Email: jokosumarsonounivet@gmail.com ${ }^{1}, \underline{\text { nurpenipriyatiningsih@gmail.com }}^{2}$, adides2016@ gmail.com $^{3}$

\begin{abstract}
This research is related to Jayabaya Musarar's forecast related to the meaning contained and the educational value in it. Jayabaya's term popularity is high among Javanese people in general and Kediri people in particular. This shows that belief in mythology is still deeply rooted in the mentality of Indonesian society. Musarar Fiber is a composition by Raden Ngabehi Ranggawarsita that needs to be preserved. The values of character education found in Musarar fibers include: 1) Values related to God, these values are found including trust and obedience to God, 2) Values related to oneself, Values including intelligence, and love of knowledge, 3) Values related with others, this value is found in the value of mutual cooperation, obedience and social rules, and justice, 4) Values related to the natural environment or the environment, this value is in the form of attitudes and actions that always try to prevent damage to the surrounding natural environment, and 5) Value related to nationality, this value can be nationalist and respect diversity.
\end{abstract}

Keywords: educational value, forecast, jayabaya. 


\section{PENDAHULUAN}

Ramalan itu berhubungan dengan tahayul, mitos, kuno, tidak ilmiah, klenik, dan mistik. Namun faktanya, ramalan adalah sisi kehidupan nyata, kehadirannya tidak dapat diabaikan. Dari sisi ilmiah, ramalan memang tidak ilmiah, tidak dapat diuji kebenarannya dengan metode ilmiah. Karena ramalan lahir dari pengamatan mata batin sang peramal. Sifat ramalan adalah spiritual, tak kasad mata. Saat peramal mengeluarkan ramalannya ia tidak bermaksud mendahului kehendak Tuhan. Ramalan tersebut bertujuan sebagai pemandu kehidupan agar bersikap hati-hati (Karim, 2009: 1).

Ramalan Jayabaya atau Jangka Jayabaya adalah ramalan dalam tradisi Jawa yang salah satunya dipercaya ditulis oleh Jayabaya, raja Kerajaan Kediri. Ramalan ini dikenal pada khususnya di kalangan masyarakat Jawa dilestarikan secara turun temurun oleh para pujangga. Asal usul utama serat ramalan Jayabaya dapat dilihat pada kitab Musarar yang digubah oleh Sunan Giri Prapen. Sekalipun banyak keraguan keasliannya, tapi sangat jelas bunyi bait pertama kitab Musasar menuliskan bahwa Jayabaya yang membuat ramalan tersebut. Kitab Musarar dibuat tatkala Prabu Jayabaya di Kediri yang gagah perkasa, musuh takut dan takluk, tak ada yang berani (Feinstein.1994: 276-280).

Jangka Jayabaya dikenal sekarang ini adalah gubahan dari Kitab Musarar, disebut juga "Kitab Asrar" karangan Sunan Giri ke-3. Kitab Asrar itu memuat lkhtisar (ringkasan) riwayat negara Jawa, yaitu gambaran gilir bergantinya negara sejak jaman purbakala hingga jatuhnya Majapahit lalu diganti dengan Ratu Hakikat ialah sebuah kerajaan Silam pertama di Jawa yang disebut sebagai "Giri Kedatan". Giri Kedatan ini nampaknya merupakan jaman peralihan kekuasaan Islam pertama di Jawa yang berlangsung antara 1478-1481 M, yakni sebelum Raden Patah dinobatkan sebagai Sultan di Demak oleh para Wali pada 1481 M. Namun demikian adanya keraton Islam di Giri ini masih bersifat "Hakikat" dan diteruskan juga sampai jaman Sunan Giri ke-3.

Sejak Sunan Giri ke-3 ini praktis kekuasaannya berakhir karena penaklukkan dilakukan oleh Sultan Agung dari Mataram; sejak Raden Patah naik tahta (1481) Sunan Ratu dari Giri Kedatan ini lalu turun tahta kerajaan, diganti oleh Ratu seluruh jajatah, ialah Sultan di Demak, Raden Patah. Jadi keraton di Giri ini kira-kira berdiri antara 1478-1481 M atau lebih lama lagi, yakni sejak Sunan Giri pertama mendirikannya atau mungkin sudah sejak Maulana Malik Ibrahim yang wafat pada tahun 1419 M (882 H). Setelah kesultanan Demak jatuh pada masa Sultan Trenggono, lalu tahta kerajaan jatuh 
ke tangan raja yang mendapat julukan sebagai "Ratu Bobodo" ialah Sultan Pajang. Julukan itu karena pengaruh kalangan Ki Ageng berorientasi setengah Budha/Hindu dan setengah Islam di bawah pengaruh kebatinan Siti Jenar, yang juga hendak di basmi pengaruhnya sejak para Wali masih hidup.

Setelah Kerajaan Demak jatuh, lalu di ganti oleh penguasa baru yakni, Ratu Sundarowang ialah Mataram bertahta dengan gelar Prabu Hanyokro Kusumo (Sultan Agung) berkuasa di seluruh Jawa dan Madura. Di kelak kemudian hari (ditinjau, dari sudut alam pikiran Sri Sultan Agung dari Mataram ini) akan muncullah seorang raja bertahta di wilayah kerajaan Sundarowang ini ialah seorang raja Waliyullah bergelar Sang Prabu Herucakra yang berkuasa di seluruh Jawa-Madura, Patani dan Sriwijaya.

Kitab Asrar digubah dan dibentuk lagi dengan cara lain, dengan jalan mengambil pokok/permulaan cerita Raja Jayabaya dari Kediri. Nama mana diketahui dari Kakawin Bharatayudha, dikarang oleh Mpu Sedah tahun 1079 Saka $=1157 \mathrm{M}$ atas titah Sri Jayabaya di Daha/Kediri. Setelah mendapat pathokan/data baru, Raja Jayabaya dikenal masyarakat sebagai pandai meramal, sang pujangga (Pangeran Wijil) lalu membuat karangan berjudul "Jangka Jayabaya" yang dipadukan antara sumber Serat Bharata yudha dengan kitab Asrar serta gambaran pertumbuhan negara-negara dikarang sebelumnya dalam bentuk babad.

Karya-karya Pujangga Agung Raden Ngabehi Ranggawarsita. Kitab ini sangat terkenal di lingkungan masyarakat Jawa, terutama pada saat terjadi krisis sosial. Dalam diri Ranggawarsita terdapat rajutan kepribadian paripurna. Di sana terkandung nilainilai kreativitas, produktivitas, moralitas dan spriritualitas. Dalam konteks reformasi peradaban kekinian, nilai-nilai luhur itu sangat relevan, karena telah terbukti mampu mengatasi ruang dan waktu (Widyawati; 2012:v).

Popularitas Jangka Jayabaya justru tergolong tinggi dikalangan masyarakat awam, terutama pada masyarakat jawa secara umum dan masyarakat Kediri khususnya. Hal ini menunjukkan bahwa kepercayaan terhadap mitologi masih berakar kuat dalam mentalitas masyarakat Indonesia. Sebuah akulturasi dan sinkretisme kepercayaan nampaknya justru semakin subur di era rasionalitas globalisasi dewasa ini. Sebagai contoh di dalam masyarakat kediri ialah emakin ramainya upacara peringatan 1 Suro di Petilasan Sri Aji Jayabaya (Sasmita, 2017). Maka, kesimpulannya adalah bahwa budaya sejarah lisan nampaknya menjadi tempat penting di khalangan masyarakat umum. 
Raden Ngabehi Ranggawarsita dalam menyusun karyanya berupa Serat Kalathida, memuat ajaran Islam dan tradisi budaya Jawa sehingga menimbulkan persinggungan antara nilai Islam dan nilai budaya Jawa. Persinggungan Islam-Jawa menjadi persoalan pelik dan telah menghasilkan sejumlah pemikiran yang patut dijadikan pertimbangan awal.

\section{METODE PENELITIAN}

Penelitian ini adalah gabungan penelitian lapangan (field research), dan penelitian perpustakaan (library research), dimana penulis focus pada bahan literasi perpustakaan dan sumber tertulis sebagai langkah awal untuk menyiapkan kerangka penelitian dan memperdalam kajian teoritis (Shamad, Irhash, A, 2003:7-13). Penelitian kepustakaan adalah penelitian yang dilakukan dengan membaca karya-karya tertulis yang terkait dengan persoalan yang dikaji (Mestika Zed, 2004:5).

Setelah mendapatkan data awal, penelitian difokuskan pada penelitian lapangan, untuk memperoleh data yang akurat. Metode sejarah merekontruksi masa lampau secara sistematis dan objektif dengan cara mengumpulkan, mengevaluasi, memperifikasi serta mensintesiskan fakta dan guna memperoleh data yang kuat dan akurat. Penulis menggunakan metode penelitian sejarah dengan langkah-langkah yaitu: heuristik, kritik sumber, sintesis, dan historiografi. Selanjutnya validitas data digunakan uji kredibilitas untuk menguji keabsahan data menggunakan triangulasi sumber.

\section{HASIL PENELITIAN DAN PEMBAHASAN}

\section{Ramalan Jaya Baya}

Tradisi Jawa mengakui, Ramalan Jayabaya ditulis oleh Prabu Jayabaya, Raja Kerajaan Kadiri/Kediri (1135-1159 Masehi) bergelar Sri Maharaja Sri Warmmeswara Madhusudanawatarani Ndita Suhrtsingha Parakrama Digjayottunggadewan Ama. Gelar itu tertera pada tiga prasasti batu ditemukan dan dikenal sebagai peninggalan sang raja, yakni prasasti Hantang (1135 M), prasasti Talan (1136 M), dan prasasti dari Desa Jepun (1144 M).

Sumber dan keterangan yang ada mengenai Ramalan Jayabaya, pada umumnya para sarjana sepakat bahwa sumber ramalan ini sebenarnya hanya satu, yakni Kitab Asrar (Musarar) karangan Sunan Giri Perapan (Sunan Giri ke-3) dikumpulkannya pada 
tahun Saka $1540=1028 \mathrm{H}=1618 \mathrm{M}$, hanya selisih 5 tahun dengan selesainya kitab Pararaton tentang sejarah Majapahit dan Singosari ditulis di pulau Bali 1535 Saka atau 1613 M. Jadi penulisan sumber ini sudah sejak zamannya Sultan Agung dari Mataram (1613-1645 M).

Kitab Jongko Joyoboyo pertama dan dipandang asli, adalah dari buah karya Pangeran Wijil I dari Kadilangu (sebutan Pangeran Kadilangu II) yang dikarangnya pada tahun 1666-1668 Jawa = 1741-1743 M. Sang pujangga ini memang seorang pangeran yang bebas. Mempunyai hak merdeka, yang artinya punya kekuasaan wilayah "Perdikan" yang berkedudukan di Kadilangu, dekat Demak.

Memang beliau keturunan Sunan Kalijaga, sehingga logis bila beliau dapat mengetahui sejarah leluhurnya dari dekat, terutama tentang riwayat masuknya Sang Prabu Brawijaya terakhir (ke-5) mengikuti agama baru; Islam, sebagai pertemuan segitiga antara Sunan Kalijaga, Brawijaya ke-V dan Penasehat sang baginda bernama Sabda Palon dan Nayagenggong.

Disamping itu beliau menjabat sebagai Kepala Jawatan Pujangga Keraton Kartasura tatkala zamannya Sri Paku Buwana II (17271749). Hasil karya Pangeran ini berupa buku-buku misalnya, Babad Pajajaran, Babad Majapahit, Babad Demak, Babad Pajang, Babad Mataram, Raja Kapa-kapa, Sejarah Empu, dan lain-lain.

\section{Sejarah Ngabehi Ronggo Warsito}

Menurut Soesilo (1999), Nama lengkap Ronggowarsito adalah Raden Ngabehi Ronggowarsito. Menurut Serat Babad Caritos Lalampahipun Swargi Raden Ngabehi Ranggawarsito, ia dilahirkan pada 10 Dulhijah tahun Jawa 1728 atau pada perhitungan Masehi tahun 1802, dengan nama Raden Bagus Burhan, sedangkan nama Raden Ngabehi Ronggowarsito adalah nama atau gelarnya ketika ia menjadi pujangga keraton. Ayahnya bernama R.T. Sartono Goroputra, putra dari Raden Ngabehi Yosodipuro II, sejak kecil ia sudah akrab dengan sastra-sastra Jawa karena ia diasuh oleh kakeknya. Darah pujangga memang telah melekat kuat pada Ronggowarsito, selain cucuYosodipuro II, ia juga cucu buyut Yasodipuro I, dan ketiganya (Yosodipuro 1, Yosodipuro II, dan Ronggowarsito) adalah pujangga istana Surakarta yang memainkan peranan utama daiam masa kebangkitan rohani dan pembaruan kepustakaan Jawa (Dian, 2004).

Menurut Simuh (1995), Ronggowarsito muda banyak mengembara mencari ilmu, di antaranya adalah menjadi santri di pondok pesantren Tegal Sari Ponorogo. Ia diasuh oleh guru 
agama kenamaan yaitu Kiai Ageng Kasan Besari, yang selain ahli agama juga merupakan ahli kebatinan dan masih berdarah priyayi. Selanjutnya Muhammad Yamin (1953), Ronggo Warsito meneruskan pengembaraannya mencari ilmu di pulau Jawa, ke tanah seberang, dan kabarnya juga sampai ke tanah India dan Sailan. Pengalaman di pesantren Tegal Sari rupanya sangat mempengaruhi kehidupannya, dan Ranggawarsito memilih meninggalkan kehidupan mudanya yang penuh kenakalan untuk menjalani peningkatan kemampuan rohaninya dengan melakukan mesu budi (Dian, 2004).

Menurut Soesilo (1999), sesudah kakeknya wafat, Ronggowarsito diangkat menjadi pujangga keraton menggantikan kakeknya, dari sinilah karirnya sebagai pujangga keraton dimulai. Ronggowarsito hidup di zaman Sri Mangkunegoro IV. Ronggowarsito memiliki murid-murid orang asing, terdiri dari pegawai bahasa di Surakarta seperti C.F. Winter, J.F.C. Grricke, dan Dr. Falmer Van Den Broug. Mereka belajar banyak tentang bahasa dan kesusastraan Jawa kepada Ronggowarsito, dan sebaliknya Ronggowarsito juga banyak belajar kesusastraan Barat dari mereka (Dian, 2004).

Menurut Soesilo (1999), selama menjadi pujangga, Ronggowarsito telah banyak rnenghasilkan karya-karya yang tidak hanya bersifat kesusastraan saja, tetapi juga mengandung unsur hukum, ekonomi, filsafat, sejarah, kebatinan, kemasyarakatan, ramalan, dongangdongang, dan lain sebagainya., Ronggowarsito bukan hanya berperan sebagai pujangga saja dalam hidupnya. tetapi ia juga seorang filsuf, apalagi karya-karyanya berbau filsafat atau ajaran kefilsafatannya menyebar luas dan menjadi pegangan hidup di kalangan rnasyarakat Jawa (Dian, 2004).

Ronggowarsito wafat pada tahun 1873 M, tepatnya pada tanggal 24 Desember, dalam usia 71 tahun, dan dimakamkan di Desa Palar, Kecamatan Trucuk, Kabupaten Klaten. Setelah mengalami penderitaan batin di masa tuanya karena kurang perhatian dari pihak istana. Delapan hari sebelum meninggal Ronggowarsito mengarang Sabda Jati berisi ramalan kematiannya di akhir bait karya tersebut (Dian, 2004).

Terkait ramalan kematiannya sendiri dalam Sabda Jati, karena Ronggowarsito memiliki kemampuan melihat ke masa depan, dan mengetahui hari kematiannya sendiri karena ia dihukum mati. Pendapat kedua ini dengan asumsi mengenai hubungan buruk yang terjadi antara Ronggowarsito dengan pihak Istana dan Belanda, Dengan mengesampingkan pendapat tersebut, memang benar Ronggowarsito wafat delapan hari setelah menulis Sabda Jati (Dian, 2004). 


\section{Nilai Pendidikan dari Serat Musarar}

Peneliti memahami nilai pendidikan merupakan pemahaman berharga akan sesuatu hal yang dapat dijadikan acuan sebagai pegangan setiap insan untuk bekal hidup secara manusiawi. Menurut Haryadi (1994:73), nilai pendidikan adalah suatu ajaran yang bernilai luhur menurut aturan pendidikan yang merupakan jembatan ke arah tercapainya tujuan pendidikan. Nilai pendidikan merupakan nilai yang dapat mempersiapkan peserta didik dalam perannya di masa mendatang melalui bimbingan, pengajaran dan latihan.

Menurut Asmani (2011: 36-40) mengelompokkan nilai-nilai pendidikan karakter menjadi empat macam sebagai berikut.

a. Nilai pendidikan karakter hubungannya dengan Tuhan. Nilai ini bersifat religius untuk memperbaiki karakter individu, yang berhubungan dengan Tuhan maupun kepercayaannya. Nilai ini dapat berupa percaya, berdoa, taat, dan bersyukur kepada Tuhan.

1) Percaya kepada Tuhan. Nilai-nilai relegius dalam Kitab Musarar disajikan dalam bentuk anjuran bagaimana manusia melakukan hubungan manusia sebagai hamba untuk memuja kepada penciptanya atau yang kuasa. Seperti yang diungkapkan dalam pupuh Asmaradana bait ke-3, dibawah ini:

\section{Lajeng angguru sayekti Sang-a Prabu Jayabaya Mring Sang raja pandhitane Rasane Kitab Musarar Wus tunumlak sadaya Lan enget wewangenipun Yen kantun nitis ping tiga.}

Terjemahan:

"Sang-a Prabu Jayabaya, Mring Sang raja pandhitane" diterjemahkan sebagai Prabu Jayabaya merupakan raja Pandhita (ulama)."

Jayabaya sebagai Raja Pandhita (pemuka agama), memiliki pengetahuan dan pengalaman. Menilik pengetahuan agama sebagai pengetahuan tentang ajaran agama meliputi berbagai segi dalam suatu agama. Sedangkan pengalaman agama adalah perasaan yang dialami orang beragama seperti rasa tenang, tenteram, bahagia, syukur, patuh, taat, takut, menyesal, bertobat, dan lain-lain (Mustari, 2014: 4). 
2) Ketaatan. Pupuh Asmaradana selanjutnya juga masih disajikan perkataan prabu Jayabaya tentang adanya guru seorang ulama (pemuka agama Islam), seperti dalam pupuh Asmaradana dibawah ini.

\section{Benjing pinernahken nenggih \\ Sang-a Prabu Jayabaya \\ Aneng sajroning tekene \\ Ing guru Sang-a Pandhita \\ Tinilar aneng Kabah \\ Imam Supingi kang nggadhuh \\ Kinarya nginggahken kutbah}

Terjemahan: "membawa tongkat seorang guru seorang Pandita (Ulama) yang tinggal di Ka'bah (Jazirah Arab), yang selalu dibawa oleh Imam Supingi (Imam Syafei)".

Pada pupuh Asmaradana diatas terkandung maksud bahwa keberadaan ulama (dalam agama Islam) sebagai tanda-tanda keberadaan ulama Islam disebutkan sebagai Iman Supangi (dalam Islam Imam Syafe'i) yang bertempat tinggal Jazirah Arab dengan Ka'bah sebagai pertanda utama.

Keberadaan Agama Islam sudah dipaparkan dalam Kitab Musarar ini. Hakikat nilai religius diwujudkan dengan nilai toleransi beragama sudah dibangun di dalam masa kekuasaan Prabu Jayabaya sebagai titisan Dewa Wisnu karena keberadaan ulama Islam diterima oleh raja, saat itu Hindu merupakan agama utama di kerajaan.

Hal ini sesuai dengan pendapat Mustari, (2014: 1), nilai religius adalah nilai karakter dalam hubungannya dengan Tuhan, nilai religius menunjukkan bahwa pikiran, perkataan, dan tindakan seseorang yang diupayakan selalu berdasarkan pada nilai-nilai Ketuhanan.

b. Nilai pendidikan karakter hubungannya dengan diri sendiri.

Nilai ini merupakan tuntunan ditujukan untuk diri pribadi, menekankan pada pengembangan rasa. Nilai ini meliputi jujur, bertanggung jawab, bijaksana, bergaya hidup sehat, disiplin, kerja keras, percaya diri, berjiwa wirausaha, berpikir logis, kritis, kreatif, inovatif, mandiri, ingin tahu, dan cinta ilmu.

1) Kecerdasan

Nilai pendidikan berkaitan dengan hubungannya dengan diri sendiri, tersaji dalam pupuh Asmaradana dibawah ini.

Dadya Sang Jayabaya ji

Waspada reh samar-samar 


\section{Kinawruhan sadurunge \\ Lakune jagad karana \\ Tindhake raja-raja \\ Saturute laku putus \\ Kalawan gaib sasmita}

Terjemahan:

'Karenanya Sang Prabu sangat digdaya, waspada terhadap segalanya, mengetahui sebelum kejadian di bumi, juga mengenai tindakan rajaraja setelahnya dengan sasmita gaib.'

Nilai pendidikan dari Asmaradana diatas bahwa Prabu Jayabaya sangat sakti memiliki kecerdasan dan kewaspadaan, serta mengetahui kejadian sebelumnya kejadian, juga mengetahui tindakan raja-raja setelah mendapatkan sasmita (pengetahuan) dari gaib (Tuhan).

Pada pupuh Asmaradana ini terlihat pada kata sasmita gaib merupakan perwujudan kecerdasan Prabu Jayabaya dalam mendengar pesan gaib dari Tuhan. Menurut Mustari (2014: 173), Kecerdasan adalah kemampuan dalam melakukan suatu tugas secara cermat, tepat dan cepat. Kecerdasan adalah istilah untuk mendiskripsikan kapaitas pikiran, selanjutnya istilah kecerdasan sebagai cara berbeda untuk memahami komunikasi, berpikir abstrak, belajar, berencana, kecerdasan emosi dan pemecahan masalah.

2) Cinta Ilmu

Nilai pendidikan selanjutnya adalah ketekunan mencari ilmu seperti diungkapkan dalam pupuh Asmaradana dibawah ini.
Yen Islama kadi nabi
Ri Sang aji Jayabaya
Cengkrameng ardi wus suwe
Apanggih lawan ki Ajar
Ajar ing gunung Padhang
Awindon tapane guntur
Dadi barang kang cinipta

Nilai pendidikan dalam pupuh Asamaradana diatas, bahwa Prabu Jayabaya lama tinggal di gunung Padang, untuk mendapatkan pengetahuan tentang Agama Islam dari Ki Ajar, dengan ketekunan belajar (tapa brata), sehingga apa yang menjadi keinginannya dapat terwujud.

Kitab Musrar diceritakan ketika Raja Jayabaya bertemu dengan pendeta (ahli agama) dari negeri Rum (Maulana Ali Samsuzen). Prabu Jayabaya menghormati beliau 
sebagai pendeta yang memiliki pengetahuan (kemampuan), terkenal, serta dapat membaca, mengerti sebelum terjadi. Raja Jayabaya kemudian diberi pengetahuan terkait jangka gaib-gaib dan tanda yang bersifat rahasia (Suyami, 2015: 125).

c. Nilai pendidikan karakter hubungannya dengan sesama.

Pada dasarnya manusia selain sebagai makhluk individu juga sebagai makhluk sosial dengan cara hidup berdampingan dengan orang lain. Nilai ini dapat berupa sadar hak dan kewajiban diri dan orang lain, patuh pada aturan sosial, santun, gotong royong, dan demokratis.

1) Gotong Royong

Pada kitab musarar juga ditemukan nilai pendidikan seperti pupuh Dhandanggula sebagai berikut.

Ilang tekan kadhatone sami
Nuli rusak iya nungsa Jawi
Nora karuwan tatane
Pra nayaka sadarum
Miwah manca negara sami
Padha sowang-sowangan
Mangkana winuwus
Mangka Allahu Tangala
Anjenengaken Sang Ratu Asmarakingkin
Bagus maksih taruna

Pada pupuh Dhandanggula diatas terkandung maksud Pulau Jawa akan rusak dan hilang istananya, ketika pejabat dan para duta besar tidak bekerjasama untuk membangun negaranya sehingga Tuhan akan mengangkat raja Asmarakingkin yang tampan dan masih muda.

2) Patuh pada Aturan sosial

Pada pupuh Dhandanggula selanjutnya dapat ditemukan nilai pendidikan sebagai berikut.

Iku mulih jeneng Narpati

Wadya punggawa sujud sadaya

Tur padha rena prentahe

Kadhatone winuwus

Ing Kediri ingkang satunggil

Kang siji tanah Ngarab

Karta jamanipun Duk semana pan pinetang

Apan sewu luwih sangang atus anenggih

Negaranira rengka 
Pupuh dhandanggula di atas menyatakan kembali pulihnya kewibawaan seorang pemimpin memberikan dampak rakyat dan para pejabat tunduk mematuhi perintahnya. Bait Wadya punggawa sujud sedaya sebagai bentuk penghormatan kepada raja atau orang yang lebih tinggi derajatnya. Pendapat Mustari (2014: 112), penerimaan serta kepatuhan kepada norma sosial adalah penting untuk mengadakan harmoni antar kelompok masyarakat.

3) Keadilan

Nilai pendidikan juga dapat diambil dari bait dibawah ini tentang keadilan.

Langkung arja jamaning narpati

Nora nana pan ingkang nanggulang

Wong desa iku wadale

Kang duwe pajeg sewu

Pan sinuda dening Narpati

Mung metu satus dinar

Mangkana winuwus

Jamanira pan pinetang

Apan sewu wolungatus anenggih

Ratune nuli sirna

Pada bait diatas diceritakan bahwa pada jaman sebelum tahun 1800, raja memperoleh kemakmuran, tidak ada yang menandingi. Keadilan digambarkan orang desa wajib membayar pajak seribu dikurangi oleh raja, menjadi hanya membayar seratus dinar (uang kecil). Pada bait ini pengurangan pajak oleh negara memberikan gambaran tentang keadilan.

Keadilan merupakan sebuah simbol dari terlaksananya kesejahteraan. Maka seorang humanis adalah seseorang menjunjung tinggi nilai keadilan. Didalam Serat Musarar dari Jayabaya khususnya pada pembabakan zaman sebelum tahun 1800 ditampilkan kondisi kesejahteraan pada jaman itu terjadi dalam suatu masyarakat. Kesejahteraan kerajaan tersebut menggambarkan bahwa rakyat semakin makmur sehingga raja yang hanya mengambil pajak dengan nilai yang sedikit sehingga pajak rakyat semakin rendah.

4) Patuh pada aturan sosial

Selanjutnya jaman berubah dengan datangnya Ratu Perangi (Belanda), kondisi menjadi menyulitkan rakyat pada saat itu, digambarkan sebagai berikut.

Wus ndilalah kersaning Hyang Widhi

Ratu Perangi anulya prapta

Wadya tambuh wilangane 


\section{Prawirane kalangkung \\ Para ratu kalah ngajurit \\ Tan ana kang nanggulang \\ Tanah Jawa gempur \\ Wus jumeneng tanah Jawa \\ Ratu Prenggi ber budi kras anglangkungi \\ Tetep neng tanah Jawa}

Pupuh Dhandanggula di atas, Ranggawarsita menangkap adanya kesenjangan antara realitas sosial dengan norma dan etika sosial yang berlaku. Maka dalam hal ini, tulisan didalam serat dapat diartikan sebagai eksplanasi seorang cendekiawan yang kritis dalam menangkap gejolak sosial. penguasa keraton yang telah ditelanjangi kekuasaannya oleh pemerintah belanda sebagai kosekuensi dari kekalahan raja, sehingga Belanda (Raja Peranggi) menjadi "raja tanah Jawa". Kekalahan ini merupakan sumber timbulnya sentimen dan jiwa nasionalisme. Maka penyesuaian Ranggawarsita yang bergaul dengan tokoh-tokoh pemerintah dan pejabat Belanda menemukan kecacatan etika dan Moral, dengan tindakannya yang sangat kejam tindakannya.

d. Nilai pendidikan karakter hubungannya dengan alam sekitar/lingkungan.

Nilai ini berupa sikap dan tindakan yang selalu berupaya mencegah kerusakan pada lingkungan alam sekitarnya. Pada kitab musarar juga ditemukan nilai pendidikan seperti pupuh Dhandanggula sebagai berikut.

Nuli rena manahe wong cilik

Jamanira den jujuluki

Gandrung-gandrung neng marga

Andulu wong gelung

Kekendon lukar kawratan

Keris parung dolen tukokena nuli

Campur bawur mring pasar

Pupuh Dhandanggula di atas terkandung maksud rakyat kecil bergembira, tidak ada yang sengsara, murah sandang pangan, semua yang ditanam tumbuh subur. Hal ini mengindikasikan alam dan lingkungan terjaga dengan baik.

Pada pupuh Dhandanggula bait ke 2, 3, dan 4 (Nora ana kang budi sangsaya, Sarwa murah tetukone, Tulus ingkang tinandur) mengindikasikan lingkungan yang terjaga sehingga tanah menjadi subur sehingga tanaman tumbuh sengan baik. Pendapat Mustari (2014: 143), ekologi sosial berakar pada keseimbangan alam, kesinambungan kemajemukan, spontanitas, dan kebebasan. Ekologi kebebasan akan menyatukan 
manusia dengan alam dan manusia dengan manusia. Untuk menghindari kerusakan ekologis, manusia harus mengakui dan hidup di dalam syarat-syarat wilayah biologisnya.ekosistem di dalam wilayah biologis membatasi pilihan manusia untuk menguasai alam.

e. Nilai pendidikan karakter hubungannya dengan kebangsaan.

Nilai ini dapat berupa nasionalis dan menghargai keberagaman. Pada kitab musarar juga di temukan karakter kebangsaan pada pupuh Sinom dibawah ini.

\section{Iku patih mengkata tumuli \\ Anggawaa ta sabalanira \\ Poma tundhungen den age \\ Yen nora lunga iku \\ Nora ingsun lilani mulih" \\ Ki Patih sigra budhal \\ Saha balanipun \\ Ya ta prapta tanah Jawa \\ Raja Prenggi tinundhung dening ki Patih \\ Sirna sabalanira}

Pupuh Dhandanggula diatas, suatu perintah raja untuk memerangi Raja Peranggi, kemudian patih kerajaan Rum berangkat ke Tanah Jawa kemudian mengusir Raja Peranggi dan Pasukannya. Nilai nasionalisme terkandung dalam pupuh Dhandanggula bait 2, 3, dan 4 (Poma tundhungen den age Yen nora lunga iku, dan Nora ingsun lilani mulih). Bait ini selaras pemikiran Mustari, (2014: 155), bahwa nasionalisme adalah cara berfikir, bersikap, dan berbuat yang menunjukkan kesetiaan, kepedulian, dan penghargaan yang tinggi terhadap bahasa, lingkungan fisik, sosial, budaya, ekonomi dan politik bangsanya.

\section{SIMPULAN DAN SARAN}

\section{Simpulan}

Berdasarkan penjelasan di depan dapat disimpulkan: 1) Serat Musarar adalah merupakan gubahan Raden Ngabei Ranggawarsita yang perlu dilestarikan salah satunya dengan mengadakan penelitian sehingga dapat terungkap kandungan dalam naskah tersebut; dan 2) Serat Musarar mempunyai nilai pendidikan yang merupakan pemahaman berharga akan sesuatu hal yang dapat dijadikan sebagai pegangan setiap insan. Nilai pendidikan karakter yang ditemukan dalam serat Musarar diantaranya: (a). Nilai yang berhubungan dengan Tuhan, bersifat religius untuk memperbaiki karakter 
individu, yang berhubungan dengan Tuhan maupun kepercayaannya. Nilai ini ditemukan diantaranya percaya dan ketaatan kepada Tuhan; (b) Nilai yang berhubungan dengan diri sendiri, nilai ini merupakan tuntunan yang ditujukan untuk diri pribadi, yang menekankan pada pengembangan rasa. Nilai ini ditemukan diantaranya kecerdasan, dan cintailmu; (c) Nilai yang berhubungan dengan sesama, Pada dasarnya manusia selain sebagai makhluk individu juga sebagai makhluk sosial dengan cara hidup berdampingan dengan orang lain. Nilai ini ditemukan diantaranya gotong royong, patuh dan aturan sosial, dan keadilan; (d) Nilai yang berhubungan dengan alam sekitar atau lingkungan, nilai ini berupa sikap dan tindakan yang selalu berupaya mencegah kerusakan pada lingkungan alam sekitarnya; dan (e) Nilai yang berhubungan dengan kebangsaan, nilai ini dapat berupa nasionalis dan menghargai keberagaman.

\section{Saran}

Berdasarkan simpulan yang disampaikan, dikemukakan saran yang diharapkan dapat bermanfaat bagi dunia pendidikan dan masyarakat. Terkait dengan hasil penelitian tentang Serat Musarar diteliti kemudian hasil penelitian diperluas sehingga dapat dibaca oleh masyarakat. Hasil penelitian dapat diambil nilai-nilai pendidikan karakter yang ada di dalamnya, selanjutnya diaplikasikan kedalam kehidupannya.

\section{DAFTAR PUSTAKA}

Alan H. Feinstein. (1994). Fakultas Sastra Universitas Indonesia. Jakarta: Yayasan Obor Indonesia.

Asmani, Jamal Ma'mur. (2011). Buku Panduan Internalisasi Pendidikan Karakter di Sekolah. Yogyakarta: Diva Press.

Gusti Garnis Sasmita, Hermanu Joebagio, Sariyatun. (2018). Humanisme dalam Serat Jangka Jayabaya Perspektif Javanese Wordview. Jurnal Studi Agama-agama. ISSN: (p) 2088-6330; (e) 2503-3778 V01. 8, No. 1 (2018); pp. 29-56

Irhas A. Shamad. (2004). Ilmu Sejarah (Perspektif Metodologis dan Acuan Penelitian). Jakarta: Hayfa Press.

Mestika Zed. (2004). Metodelogi Penelitian Kepustakaan. DKI Jaya: Yayasan Obor Indonesia.

Poespoprodjo. W. (1987). Subjektivitas Dalam Historiografi. Bandung: Remadjakarya. 
Shamad, Irhash, A. (2003). Ilmu Sejarah Perspektif Metodologi dan Acuan Penelitian. Jakarta: Hayfa Press.

Suyami. (2015). Kajian Budi Pekerti dalam Serat Jayabaya. Yogyakarta: Balai Pelestarian Nilai Budaya Yogyakarta.

Widyanarko, Dian. (2004). Unsur-unsur Filsafat Sejarah dalam Pemikiran R.Ng. Ronggo Warsito, Jurnal Filsafat. April 2004. Jilid 36. Nomor 1. Hal 33. 